\title{
LOAD TRANSFER PLATFORMS - COMPARISON OF DESIGN METHODS
}

\author{
Jelena Kaluđer \\ GT-TRADE d.o.o., mag.ing.aedif. \\ Mensur Mulabdić \\ Josip Juraj Strossmayer University of Osijek, Faculty of Civil Engineering Osijek, Full Professor \\ Krunoslav Minažek \\ Josip Juraj Strossmayer University of Osijek, Faculty of Civil Engineering Osijek, Assistant Professor \\ Corresponding author: krumin@gfos.hr
}

\begin{abstract}
Constructing embankments on compressible foundation soil normally requires soil improvement measures to reduce the amount and duration of settlement. In the most difficult cases, the soil is improved by using pile foundations. When constructing pile foundations, it is necessary to ensure efficient load transfer from the embankment to the piles, which can be achieved using reinforced soil construction with geosynthetics as reinforcement material. In this paper, we compare the calculations of a bearing capacity of such a platform according to the British and the German standards on the example of a level crossing over a railway line. We describe other calculation methods, critically reviewing the fundamental mechanisms of the reinforcement effects in the calculations.
\end{abstract}

Keywords: embankment foundation, reinforced soil structure over piles, calculation methods

\section{NOSIVE PLATFORME ZA PRIJENOS OPTEREĆENJA - USPOREDBA PRORAČUNSKIH METODA}

Sažetak: Izvedba nasipa na stišljivom temeljnom tlu redovito zahtijeva mjere poboljšanja temeljnog tla kako bi se smanjio iznos i vrijeme slijeganja. Rješenje najtežih slučajeva postiže se upotrebom pilota. U slučaju izvedbe pilota potrebno je osigurati djelotvoran prijenos opterećenja od nasipa na pilote, što se može postići izvedbom platforme od armiranog tla koristeći geosintetike kao armaturu. U radu je prikazan proračun nosivosti ovakvih platformi i usporedba rezultata proračuna po dva standarda: britanskom i njemačkom, na primjeru cestovnog prijelaza preko željezničke pruge. Opisane su i ostale metode proračuna, uz kritički osvrt na način na koji se bitna svojstava korištene armature uvažavaju u proračunu.

Ključne riječi: temeljenje nasipa, nosive platforme od armiranog tla, metode proračuna 


\section{INTRODUCTION}

The main characteristics of soft soil are excessive compressibility, low shear strength, insufficient bearing capacity, and a tendency toward long-term consolidation settlement. As a consequence of these properties, embankments built on soft soil tend to deform after many years following their construction. This is often a problem in roads and railroads, where these issues can be alleviated using modern or some of the traditional soil improvement techniques. Traditional techniques include mechanical, hydraulic, and physical-chemical modification, as well as preloading of the foundation soil, the oldest technique. However, the total construction time is often not long enough to allow for consolidation settlement, necessitating the use of a modern technique. Modern soil improvement techniques involve the use of geosynthetics, which prevent the subsoil and embankment fill mixing, allow filtration and drainage, and with their high tensile strength they improve the mechanical properties of the soil. When building on a deep, soft subsoil strata, load transfer to the load-bearing layer or firmer stratum can be achieved by using a geosynthetics-reinforced soil structure over gravel, concrete or reinforced concrete piles which form the point or linear support for the reinforced soil structure. This load-transfer platform, located between the embankment and the piles, is a composite of the granular material compacted between several horizontal layers of high-strength geosynthetics. In the load-bearing platform, the geosynthetics have three functions: they increase the pressure on the piles, restrict and annul the lateral spreading at the embankment edge, and also separate the embankment from the foundation soil [1].

Geosynthetics-reinforced load-transfer platforms have been used often since the 1970s [2-5]. These platforms are very effective in areas where the soil surface is prone to erosion, demolition, or degradation, which is typical for abandoned mines and karstic landscapes. There is a danger in these areas of cavities expanding toward the ground surface (i.e., sink holes opening), but constructing reinforced soil structures over piles significantly reduces this risk [6].

\section{REINFORCED SOIL PLATFORMS OVER POINT OR LINEAR BEARING ELEMENTS METHODOLOGY}

The main purpose of a reinforced-soil platform is to transfer all load from the embankment on a solid base at a certain depth by point or linear bearing elements - piles, as shown in the cross-section of an embankment at Figure 1. Piles can have square or round cross-sections and can be arranged in a regular rectangular or triangular grid (Figure 2). In a rectangular grid, the piles are arranged in a square relative to the longitudinal axis of the structure; in a triangular grid, they are arranged in a is a square rotated for a $45^{\circ}$ relative to the longitudinal axis of the structure.

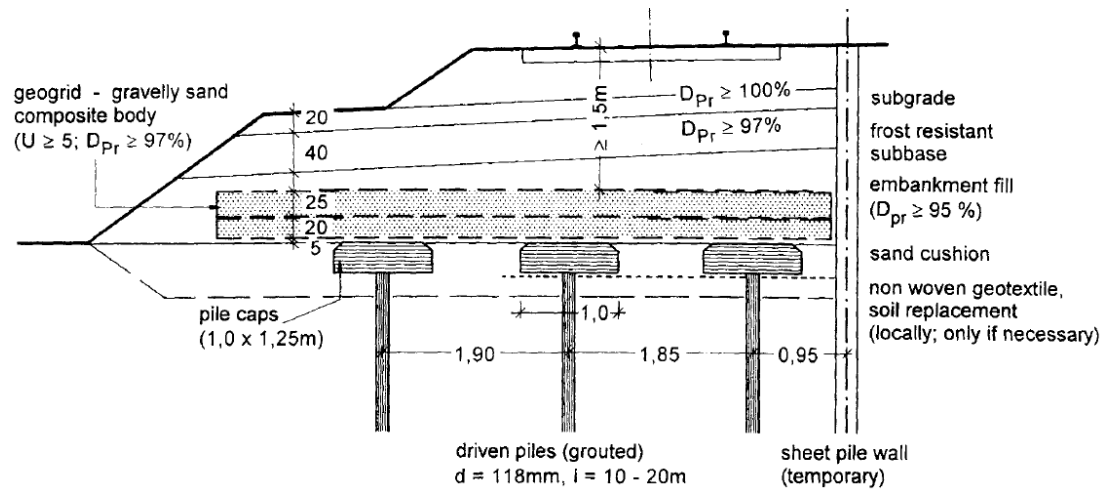

Figure 1 Cross-section of a reinforced earth structure over point bearing elements [7]

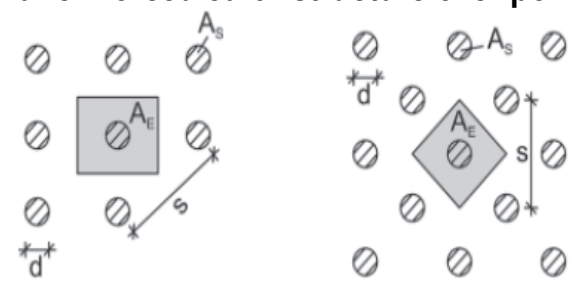

Figure 2 Arrangement of point bearing elements in rectangular and triangular grids [8] 
Reinforcing the soil platform with horizontally placed geosynthetics provides additional support to overcome the bridging distance between piles, and it is designed to ensure load transfer to piles by redistributing internal load and to prevent punching effects.

Load-transfer platforms can be designed using various computational and analytical methods. All analytical methods account for the stress-strain relationship in all elements of the system; this process establishes the load redistribution, showing which part of the total load is carried directly by the piles (pile caps) and which part is carried by the geosynthetic reinforcement between the piles. Figure 3 shows the load transfer mechanism of such a reinforced structure. The reinforcement is subjected to stress which comes from a vertical load between the piles. This membrane effect decreases with arching $\left(p_{b}\right)$ and subgrade reaction below the reinforcement $\left(\sigma_{s}\right)$.

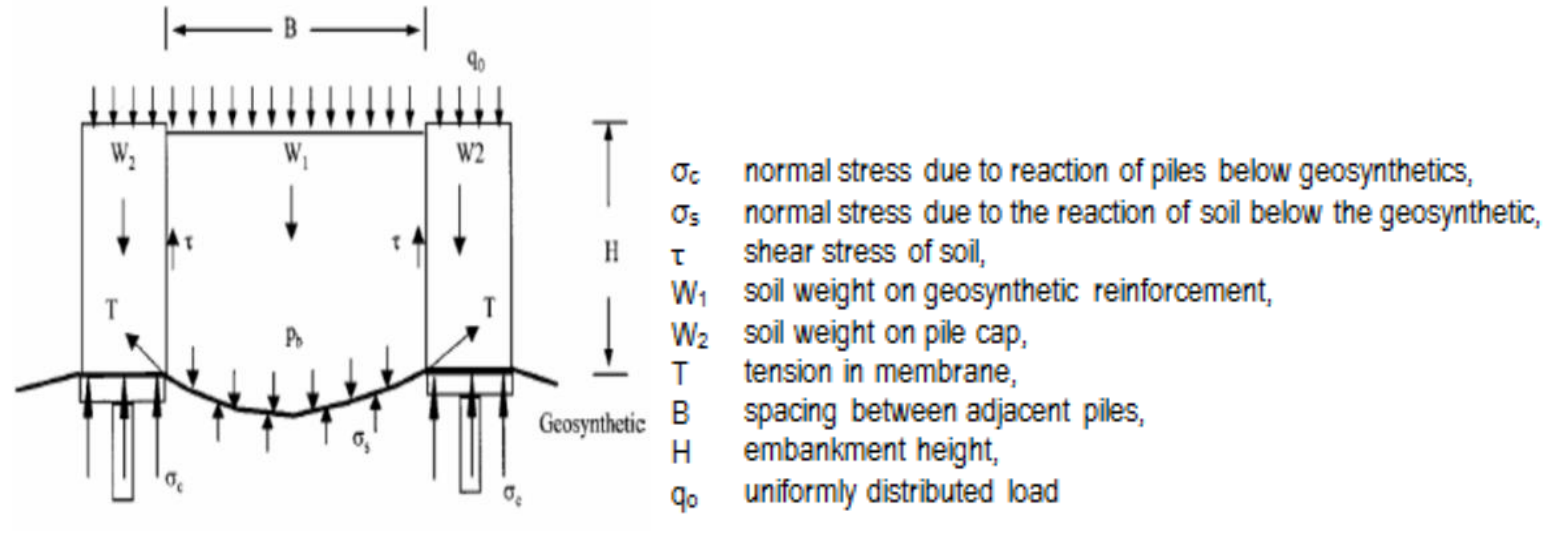

Figure 3 Mechanism of load transfer in a reinforced earth structure over piles [9]

\subsection{Load transfer in reinforced earth structure over point bearing elements}

In the calculation of the reinforced soil platform, the arching effect is the key mechanism for load transfer, which prevents formation of differential settlement in the embankment. Several calculation methods have been developed for reinforced soil platforms, the most important being Guido [10], Swedish [11], Hewlett and Randolph [12], British BS 8006 [13], and German EBGEO [8]. The main features of these methods listed are as follows. The Guido method represents is a very simplified approach for load transfer [10]. It assumes that the angle of load spreading through the geosynthetic reinforcement in the granular material is $45^{\circ}$ (Figure 4). The height of the pyramidal formed soil, whose load is taken by the reinforced soil fill, does not reach the surface (i.e., the full embankment height), which is unacceptable for load from railway transport.

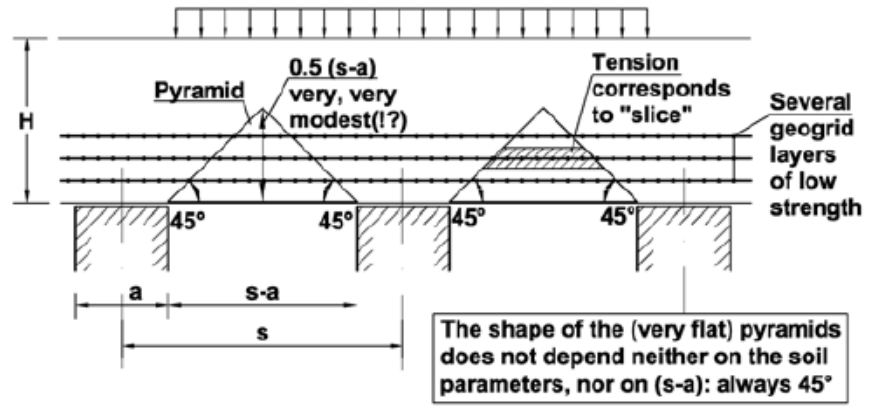

Figure 4 The Guido method for modeling reinforced earth structure over piles [11]

The Swedish method [11] is a simplified model that accounts for the following principles: the reinforcement must always carry the load of the soil in the shape of a truncated pyramid with a $75^{\circ}$ inclination; the truncated pyramid reduces the load carried by the piles and takes over the traffic surcharge (Figure 5). The Swedish method is used in Scandinavian countries. 


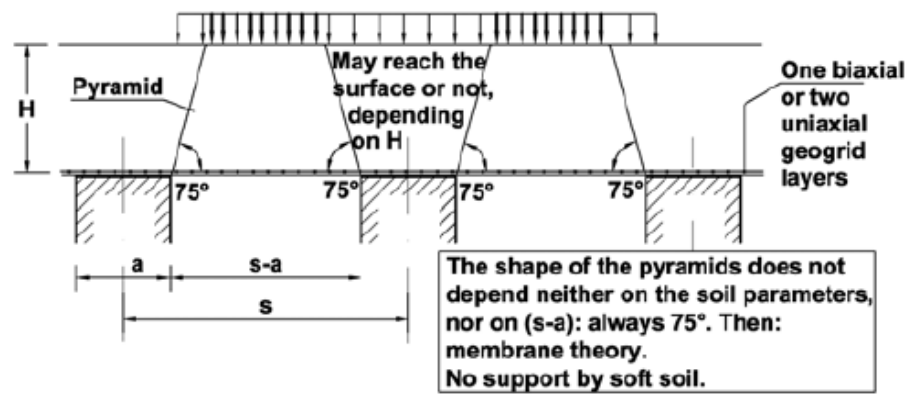

Figure 5 The Swedish method for modeling reinforced earth structure over piles [11]

Hewlett and Randolph [12] found a theoretical solution for designing a reinforced earth structure on granular drained soils. They assumed that the load of the embankment is transferred with a series of semi-circular domes supported by pile caps (Figure 6). In this case, the critical bearing capacity zones are the crown of the dome and/or the pile caps. Increased arch of load transfer platform reinforces the well-graded material and helps form the interlocking mechanism.

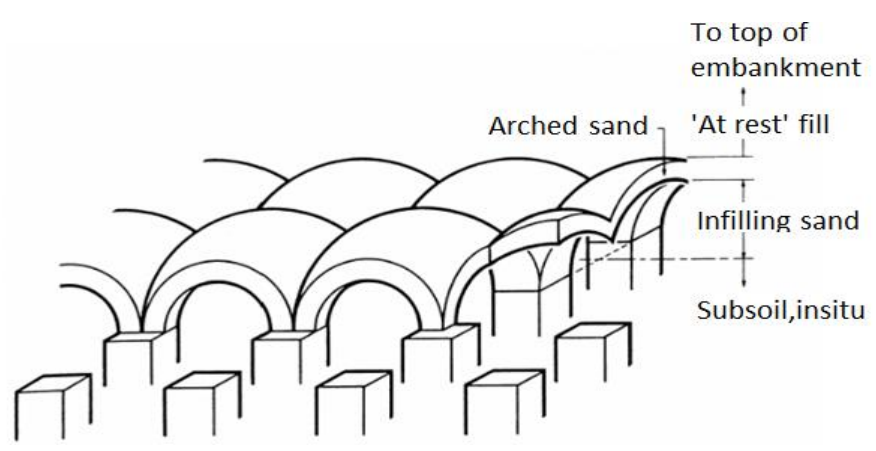

\section{Figure 6 The Hewlett and Randolph method for modeling a reinforced earth structure over piles [13]}

The first design approaches of the British Standard (BS 8006) were explained in 1987 and 1990 [13], and the accepted standard has been used since 1995. This model makes a simplified 3D assumption that the arching in the embankment fill always has a semi-spherical shape, regardless of material type, and it is equal for fine sand and crushed gravel (Figure 7). The force in the geosynthetics is calculated using membrane theory from the loads of the soil below the arch. The reinforcement is placed in one or two layers above the piles. There is no upward counter pressure between piles i.e. tangential stresses of the soil. This standard does not account for the participation of the soft soil in the support for the reinforced soil platform over the piles. The load on the reinforcement (geosynthetics) is transferred as a line load on a reinforcement strip between adjacent pile caps, and the relation between the line loads, strain, and tensile force in the geosynthetic reinforcement is given by the link chain equation.

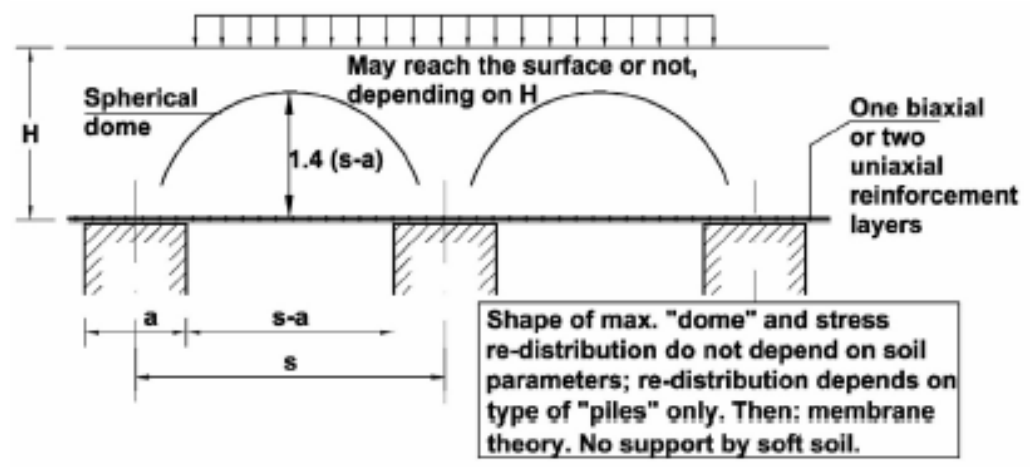

Figure 7 The British Standard 8006 method for modeling a reinforced soil platform over piles [11] 
The German method (EBGEO) [8] combines the load redistribution according to Hewlett and Randolph [12] accounting for the internal friction angle of the soil near the full height of the reinforced soil platform and the membrane theory applied in the British Standard. The shape of the load redistribution (arching) is a multi-spherical dome, and for the calculation of tensile forces in reinforcement strains and the edometer moduli of soft soils are relevant (Figure 8). The German method recommends one or at most two layers of the high-strength reinforcement over the piles, rather than multiple layers of lower-strength reinforcement. The critical bearing capacity zones are the crown of the dome and the pile caps, while the load redistribution depends on the soil characteristics and surcharge; in essence, it depends on the embankment height and pile distance. Table 1 compares the calculation methods.

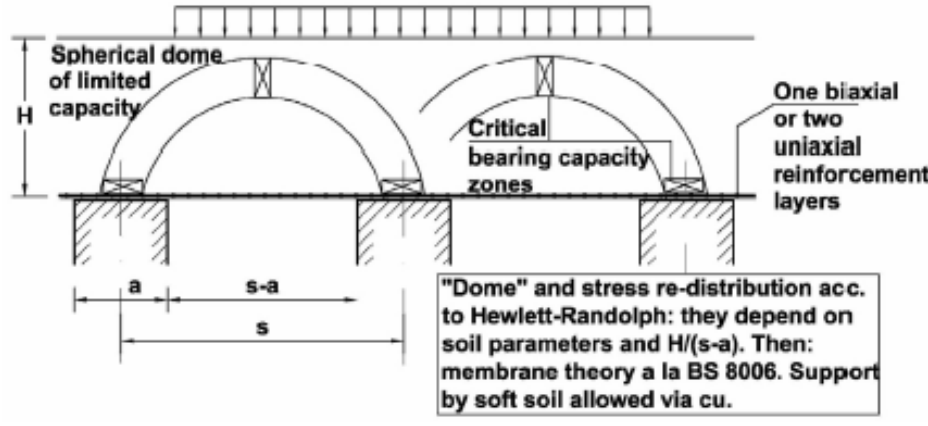

Figure 8 The older German method for modeling a reinforced earth structure over piles [11]

Table 1 Comparison of methods according to criteria

\begin{tabular}{|c|c|c|c|c|c|c|c|}
\hline \multirow[b]{2}{*}{ Method } & \multicolumn{7}{|l|}{ Criteria } \\
\hline & Arching & $\begin{array}{l}\text { Soil } \\
\text { characteristics }\end{array}$ & $\begin{array}{l}\rho \text { (internal } \\
\text { friction angle } \\
\text { of the soil) }\end{array}$ & $\begin{array}{l}\text { Traffic } \\
\text { surcharge }\end{array}$ & $\begin{array}{l}\text { Load } \\
\text { transfer }\end{array}$ & $\begin{array}{l}\text { Number of } \\
\text { geosynthetic } \\
\text { layers }\end{array}$ & $\begin{array}{l}\text { SSR (stress } \\
\text { reduction ratio) }\end{array}$ \\
\hline GUIDO [10] & $\begin{array}{l}\text { pyramid of pile } \\
\text { half distance } \\
\text { height }\end{array}$ & $\begin{array}{l}\text { does not take } \\
\text { into account }\end{array}$ & $>45^{\circ}$ & $\begin{array}{l}\text { does not } \\
\text { take into } \\
\text { account }\end{array}$ & $\begin{array}{l}\text { tensioned } \\
\text { membrane }\end{array}$ & $>3$ & $\begin{array}{l}\text { for the entire } \\
\text { platform }\end{array}$ \\
\hline $\begin{array}{l}\text { SWEDISH } \\
\text { [11] }\end{array}$ & $\begin{array}{l}\text { pyramid of } \\
\text { height up to } \\
\text { embankment } \\
\text { surface }\end{array}$ & $\begin{array}{l}\text { does not take } \\
\text { into account }\end{array}$ & - & $\begin{array}{l}\text { take into } \\
\text { account }\end{array}$ & $\begin{array}{l}\text { tensioned } \\
\text { membrane }\end{array}$ & $1-2$ & $\begin{array}{l}\text { for the entire } \\
\text { platform }\end{array}$ \\
\hline $\begin{array}{l}\text { HEWLETT- } \\
\text { RANDOLPH } \\
\text { [12] }\end{array}$ & domes & graded soil & - & - & arch & $>1$ & $\begin{array}{l}\text { on crown of } \\
\text { dome and pile } \\
\text { cap }\end{array}$ \\
\hline BS 8006 [13] & semi-sphere & $\begin{array}{l}\text { does not take } \\
\text { into account }\end{array}$ & - & - & $\begin{array}{l}\text { tensioned } \\
\text { membrane }\end{array}$ & $1-2$ & $\begin{array}{l}\text { for the entire } \\
\text { platform }\end{array}$ \\
\hline EBGEO [8] & $\begin{array}{l}\text { multi-spherical } \\
\text { dome }\end{array}$ & $\begin{array}{l}\text { significant for } \\
\text { calculation }\end{array}$ & $\begin{array}{l}\text { significant for } \\
\text { calculation }\end{array}$ & $\begin{array}{l}\text { significant } \\
\text { for } \\
\text { calculation }\end{array}$ & $\begin{array}{l}\text { tensioned } \\
\text { membrane }\end{array}$ & $1-2$ & $\begin{array}{l}\text { for the entire } \\
\text { platform }\end{array}$ \\
\hline
\end{tabular}

\subsection{Calculation of reinforced earth structure over piles according to British Standard BS 8006}

In calculating the load on the geosynthetic reinforcement in a reinforced earth structure over piles, the British standard [13] uses four assumptions: the load on the pile caps can be calculated with an adjusted equation by Marston for pipes (1); the soft soil is not participating in the support; the load on the reinforcement $\left(p_{r}^{\prime}\right)$ is transferred to the line load $\left(W_{T}\right)$ on the reinforcement strip between adjacent pile caps; and the relation between the line load $\left(W_{T}\right)$, strain $\varepsilon$, and tensile force in the geosynthetic reinforcement is expressed by the chain link equation. BS 8006 simulates the load redistribution on the pile caps, $p_{c}^{\prime}$, and the load redistribution on the soil between the piles, $p_{r}^{\prime}$ (Figure 9). However, the load carried by the reinforcement between the piles is not specifically elaborated in the British standard. In Figure 9, part of the load directly transferred to the pile caps is marked as load A. Another part of the load, load B, represents the weight of the soil below the virtual arch, which acts on the reinforcement and is transferred to the piles. The British standard assumes there is no support from the soft subsoil; i.e., load $C=0$. 

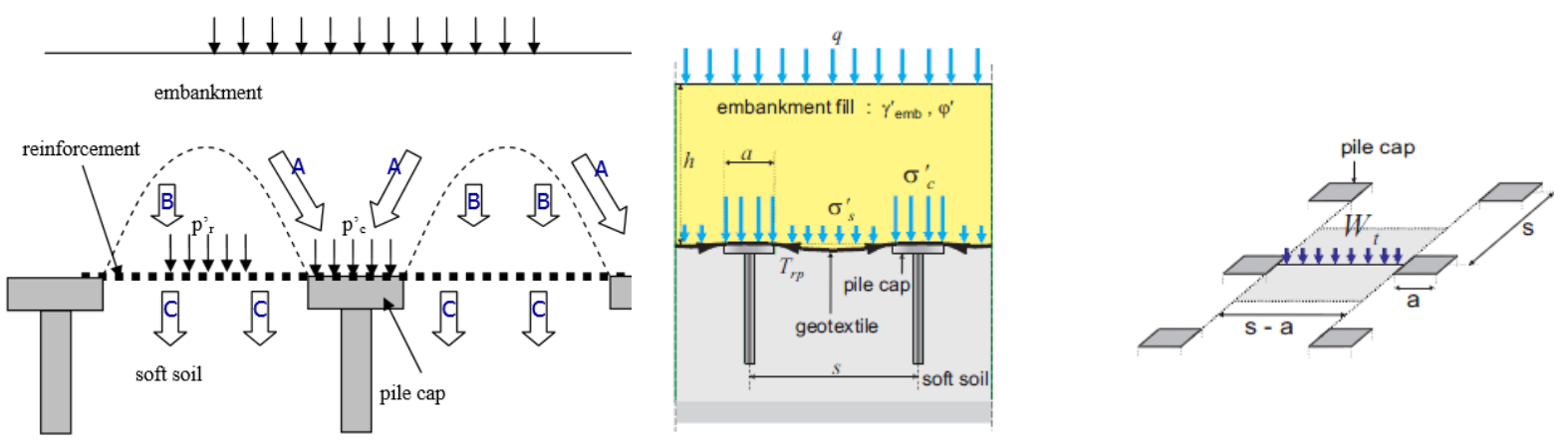

Figure 9 The load redistribution on the geosynthetic reinforcement in a load transfer platform $[14,15]$

Table 2 gives partial factors from the British standard for designing reinforced earth structure over piles.

Table 2 Partial factors for designing reinforced earth structure by BS 8006 [13]

\begin{tabular}{|l|l|l|l|}
\hline \multicolumn{2}{|c|}{ Partial factors } & Ultimate limit state & Serviceability limit state \\
\hline \multirow{3}{*}{ Load factors } & Soil unit mass & $f_{\mathrm{fs}}=1.3$ & $f_{\mathrm{fs}}=1.0$ \\
\cline { 2 - 4 } & External dead loads & $f_{\mathrm{f}}=1.2$ & $f_{\mathrm{f}}=1.0$ \\
\cline { 2 - 4 } & External live loads & $f_{\mathrm{q}}=1.3$ & $f_{\mathrm{q}}=1.0$ \\
\hline $\begin{array}{l}\text { Soil material } \\
\text { factors }\end{array}$ & To be applied to tan $\emptyset_{\mathrm{cv}}{ }^{\prime}$ & $f_{\mathrm{ms}}=1.0$ & $f_{\mathrm{ms}}=1.0$ \\
\hline $\begin{array}{l}\text { Soil/reinforcement } \\
\text { interaction factors }\end{array}$ & Sliding across surface of reinforcement & $f_{\mathrm{s}}=1.3$ & $f_{\mathrm{s}}=1.0$ \\
\cline { 2 - 4 } & Pull-out resistance of reinforcement & $f_{\mathrm{p}}=1.3$ & $f_{\mathrm{p}}=1.0$ \\
\hline
\end{tabular}

The adjusted equation by Marston for calculating the direct load on the pile caps is:

$$
\frac{p_{c}^{\prime}}{\sigma^{\prime}{ }_{v}}=\left(\frac{a C_{c}}{h}\right)^{2}
$$

where $C_{c}$ is the arching coefficient, calculated by the following equations:
For end-bearing piles:
$C_{c}=1.95 \frac{h}{a}-0.18$
For friction and other piles:

$$
C_{c}=1.5 \frac{h}{a}-0.07
$$

The average vertical stress at the base of the embankment is expressed by $\sigma^{\prime}{ }_{v}=\gamma \mathrm{h}+\mathrm{p}$

The line load $W_{T}$ carried by the reinforcement strip between two adjacent pile caps is expressed by the following equations:

For full arching, $h>1.4 \cdot(\mathrm{s}-\mathrm{a}): \quad \mathrm{W}_{\mathrm{T}}=\frac{\mathrm{sf}_{\mathrm{fs}} \gamma(\mathrm{s}-\mathrm{a})}{\mathrm{s}^{2}-\mathrm{a}^{2}} \cdot\left(\mathrm{s}^{2}-\mathrm{a}^{2}\left(\frac{\mathrm{p}_{\mathrm{c}}}{\sigma_{\mathrm{v}}}\right)\right)$

For partial arching, 0.7·(s-a) $\leq H \leq 1.4 \cdot(s-a): W_{T}=\frac{s \cdot\left(f_{f s} \gamma H+f_{\mathrm{q}} w s\right)}{s^{2}-a^{2}} \cdot\left(s^{2}-a^{2}\left(\frac{p_{c}}{\sigma_{v}}\right)\right)$

The tensile load in the reinforcement is given by link chain equation: $T_{\mathrm{rp}}=\frac{W_{T}(s-a)}{2 a} \sqrt{1+\frac{1}{6 \varepsilon}}$

where $\varepsilon$ is the strain in the geosynthetic layer, which is calculated by: $\varepsilon=\frac{8 \cdot d^{2}}{3 \cdot(s-a)^{2}}$

\subsection{Calculation of reinforced earth structure over piles according to the German Standard EBGEO}

Figure 10 shows a model of load redistribution within a reinforced soil platform and the membrane action of the geosynthetic reinforcement.

For piles arranged in a rectangular grid, the stresses on the ground between them are calculated numerically or read from the graphs, taking into account whether the effects are permanent or permanent and variable. Graphically determining the stresses $\sigma_{\text {zok }}$ depends on the friction angle of the reinforced earth structure, $\varphi_{\mathrm{k}}^{\prime}$. Figure 11 illustrates a graphical determination of normal stresses for $\varphi_{k}^{\prime}=30^{\circ}$. 


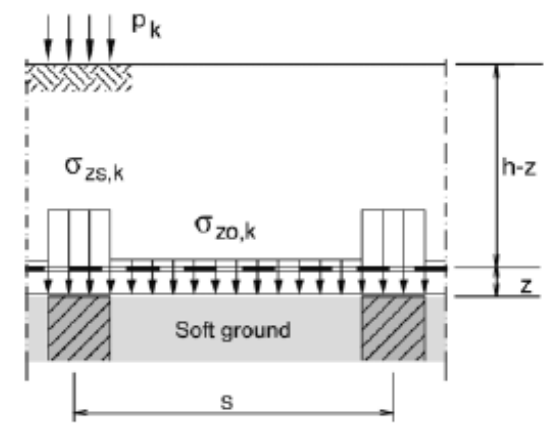

Figure 10 Stress redistribution in a reinforced earth structure [8]

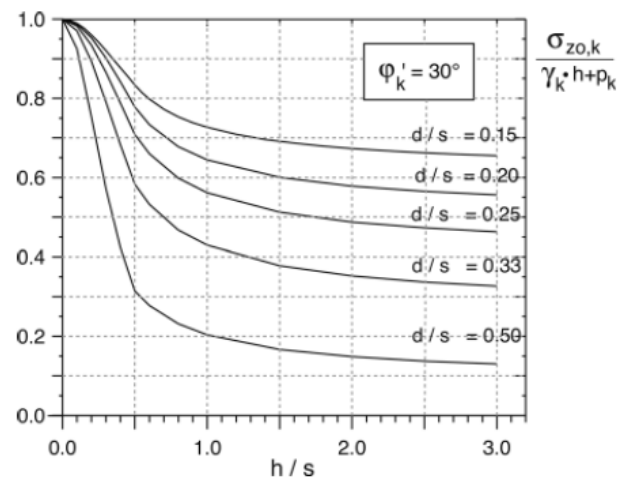

Figure 11 Graphical determination of stresses at $\varphi^{\prime} k=30^{\circ}[8]$

A numerical determination of stresses on soil between the support surface considers the effects of both the permanent and permanent and variable actions, which are expressed with the following equations:

$\sigma_{\mathrm{zo}, \mathrm{G}, \mathrm{k}}=\lambda_{1}^{\chi} \cdot\left(\gamma_{\mathrm{k}} \cdot \frac{\mathrm{p}_{\mathrm{G}, \mathrm{k}}}{\mathrm{h}}\right) \cdot\left\{\mathrm{h} \cdot\left(\lambda_{1}+\mathrm{h}_{\mathrm{g}}^{2} \cdot \lambda_{2}\right)^{-\chi}+\mathrm{h}_{\mathrm{g}} \cdot\left[\left(\lambda_{1}+\frac{\mathrm{h}_{\mathrm{g}}^{2} \cdot \lambda_{2}}{4}\right)^{-\chi}-\left(\lambda_{1}+\mathrm{h}_{\mathrm{g}}^{2} \cdot \lambda_{2}\right)^{-\chi}\right]\right\}$

$\sigma_{\mathrm{zo}, \mathrm{G}+\mathrm{Q}, \mathrm{k}}=\lambda_{1}^{\chi} \cdot\left(\gamma_{\mathrm{k}} \cdot \frac{\mathrm{p}_{\mathrm{G}+\mathrm{Q} \mathrm{k}}}{\mathrm{h}}\right) \cdot\left\{\mathrm{h} \cdot\left(\lambda_{1}+\mathrm{h}_{\mathrm{g}}^{2} \cdot \lambda_{2}\right)^{-\chi}+\mathrm{h}_{\mathrm{g}} \cdot\left[\left(\lambda_{1}+\frac{\mathrm{h}_{\mathrm{g}}^{2} \cdot \lambda_{2}}{4}\right)^{-\chi}-\left(\lambda_{1}+\mathrm{h}_{\mathrm{g}}^{2} \cdot \lambda_{2}\right)^{-\chi}\right]\right\}$

where $p_{\mathrm{G}, \mathrm{k}} p_{\mathrm{G}+Q, \mathrm{k}}$ are characteristic values of the permanent and the permanent and variable distributed loads on the reinforced earth structure top with an arch height $h_{g}, X$ is a dimensionless coefficient, and $\lambda$ is the composite friction coefficient.

The stress on the vertical bearing elements (piles) is calculated using:

$$
\begin{aligned}
& \sigma_{z s, G, k}=\left[\left(\gamma_{k} \cdot h+p_{G, k}\right)-\sigma_{z o, G, k}\right] \cdot \frac{A_{E}}{A_{s}}+\sigma_{z 0, G, k} \\
& \sigma_{z s, G,+Q k}=\left[\left(\gamma_{k} \cdot h+p_{G+Q, k}\right)-\sigma_{z o, G+Q, k}\right] \cdot \frac{A_{E}}{A_{s}}+\sigma_{z 0, G+Q, k}
\end{aligned}
$$

where $A_{E}$ is the zone of influence of the bearing elements, and $A_{S}$ is the support area (Figure 2).

\section{EXAMPLE CALCULATION OF A LOAD TRANSFER PLATFORM ON AN ACCESS RAMP EMBANKMENT}

Here we show an example solution of an actual problem: designing the foundation of an access ramp on the soft subsoil of a flyover across railroad tracks located in central Croatia, using a reinforced soil platform over piles. The platform is supported on piles that form point bearing support for the reinforced soil structure. Two alternative solutions were analyzed: one for reinforcement with geogrids and the other with geotextile reinforcement. Also, we calculated the end-bearing piles and friction piles using the EBGEO and BS8006 standards.

The geotechnical composition and soil characteristics were determined with in situ investigations and laboratory testing in a geotechnical project [16]. The parameters of the embankment fill soil were: unit weight of 20 $\mathrm{kN} / \mathrm{m}^{3}$ and internal friction angle of $42^{\circ}$. Table 3 gives the subsoil parameters, which were taken from the geotechnical investigation report. 
Table 3 Soil parameters [17]

\begin{tabular}{|l|l|l|l|l|l|l|}
\hline Subsoil & Interval & $\boldsymbol{h}_{\mathrm{i}}(\mathbf{m})$ & $\boldsymbol{\gamma}_{\mathbf{k}, \mathbf{i}}^{\prime}\left(\mathbf{k N} / \mathbf{m}^{3}\right)$ & $\boldsymbol{C u k}_{\mathrm{uk}}(\mathbf{k P a})$ & $\boldsymbol{\varphi}_{\mathbf{k}, \mathbf{i}}^{\prime}\left(^{\circ}\right)$ & $\boldsymbol{M}_{\mathbf{k}}\left(\mathbf{k N} / \mathbf{m}^{2}\right)$ \\
\hline $\mathbf{1}$ & $0.0-2.3$ & 2.30 & 19 & 50 & - & 6500 \\
\hline $\mathbf{2}$ & $2.3-4.0$ & 1.70 & 9 & - & 26 & 2500 \\
\hline $\mathbf{3}$ & $4.0-6.0$ & 2.00 & 9 & - & 28 & 7000 \\
\hline $\mathbf{4}$ & $6.0-10.4$ & 4.40 & 9 & - & 32 & 14000 \\
\hline $\mathbf{5}$ & $10.4-16.5$ & 4.10 & 9 & 160 & - & 12000 \\
\hline $\mathbf{6}$ & $16.5-19.4$ & 2.90 & 9 & - & 31 & 17000 \\
\hline $\mathbf{7}$ & $19.4-22.9$ & 3.50 & 9 & 160 & - & 15000 \\
\hline $\mathbf{8}$ & $22.9-30.0$ & 7.10 & 9 & 140 & - & 11000 \\
\hline
\end{tabular}

The geosynthetics selected for the load transfer platform were geogrids and geotextiles. The pile arrangement formed a rectangular grid with equal spacing in both directions, with $s_{x}=s_{y}=1.50 \mathrm{~m}$. The pile diameter was $0.70 \mathrm{~m}$, and the length was $19.80 \mathrm{~m}$. The biaxial geogrids and woven geotextiles selected had short-term strengths of 200 $\mathrm{kN} / \mathrm{m}$ and $175 \mathrm{kN} / \mathrm{m}$, respectively. Figure 12 shows the solution for the reinforced soil platform for the access ramp embankment.

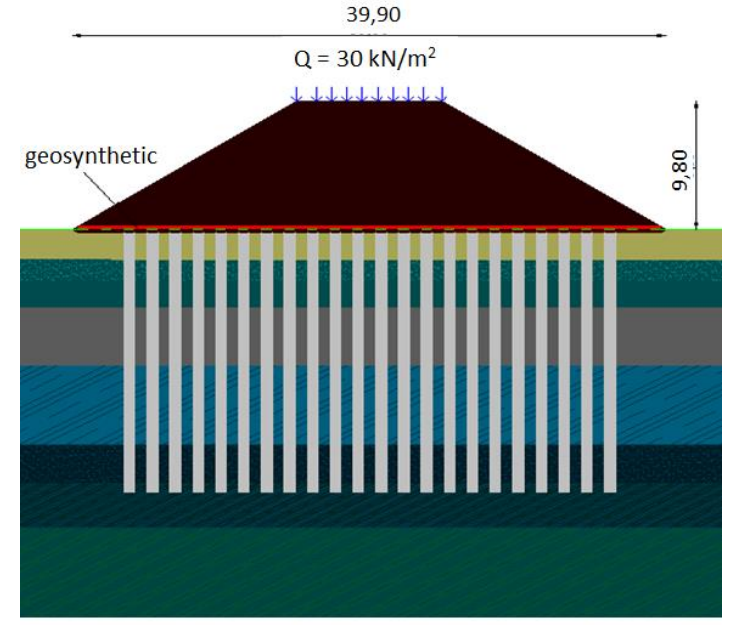

Figure 12 Schematic of the access zone of the flyover (suggested solution)

We calculated reinforced soil platform over the piles according to the EBGEO and BS8006 standards using the previously described equations; these results are shown in Table 4 and graphically in Figure 13. The calculated load redistributions in BS 8006 were different between the friction piles and end-bearing piles. The German standard only provides a method for calculating end-bearing piles. The results from EBGEO and BS 8006 are similar in load transferred directly to the end-bearing piles. However, the calculated loads carried by the geosynthetics are smaller for EBGEO than for BS 8006 (end-bearing piles). The reason for this difference is that BS 8006 does not account for the participation of the soft subsoil.

Table 4 Load redistributions according to EBGEO and BS 8006

\begin{tabular}{|l|l|l|l|}
\hline & EBGEO & BS 8006(2D) Friction and other piles & BS 8006 (2D) End-bearing piles \\
\hline Total load (kN) & 508.5 & 508.5 & 508.5 \\
\hline Load directly on piles (kN) & 464.15 & 274.30 & 463.89 \\
\hline Load carried by geosynthetic (kN) & 22.18 & 234.20 & 30.78 \\
\hline Load carried by soft subsoil $(\mathbf{k N})$ & 22.17 & - & - \\
\hline Vertical line load $\boldsymbol{w}_{\boldsymbol{T}}(\mathbf{k N} / \mathbf{m})$ & 19.52 & 206.79 & 27.12 \\
\hline Tensile force $\boldsymbol{F}$ in reinforcement $\mathbf{( k N )}$ & 29.26 & 271.89 & 35.66 \\
\hline
\end{tabular}




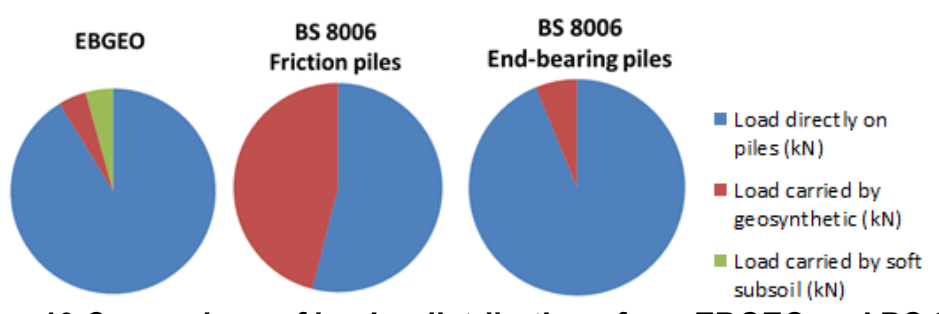

Figure 13 Comparison of load redistributions from EBGEO and BS 8006

According to Van Eekelen, Bezuijen and Alexiew [17], who compared calculated values (from standard calculations given in EBGEO and BS 8006) and measured values, the British standard (BS 8006) better predicted the load transfer to the piles than did the German standard (EBGEO). This is shown in Figure 14, where the BS 8006 results (blue line) fits the measured values, while the EBGEO results (dashed red line) are about 1.5 times greater than the measured values. Figure 15 shows that the EBGEO standard better predicts the vertical loads on the geosynthetics than the BS 8006; the EBGEO results almost match, while the BS 8006 results are 2.5 to 3 times higher than the measured values. This misfit exists because BS 8006 does not account for the support of subsoil in carrying the load.

There are differences between the load redistribution in the load transfer platform of the access ramp described here and that in previous research [17] because they have different embankment and pile geometries as well as differences in the characteristics of the foundation and embankment soil.

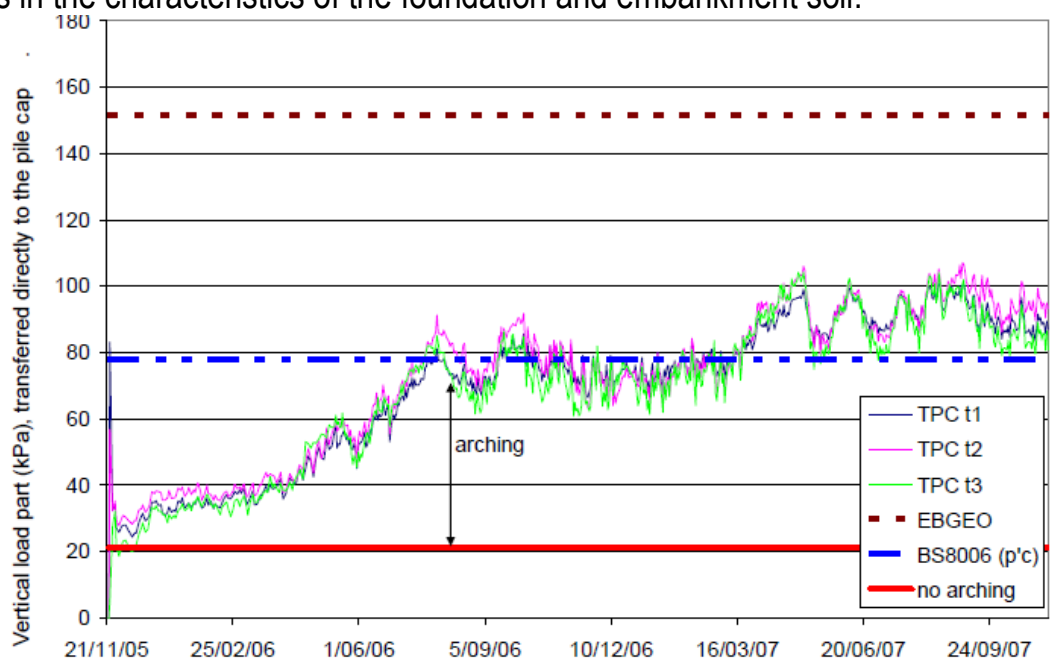

Figure 14 Vertical load transferred directly to the piles [17]

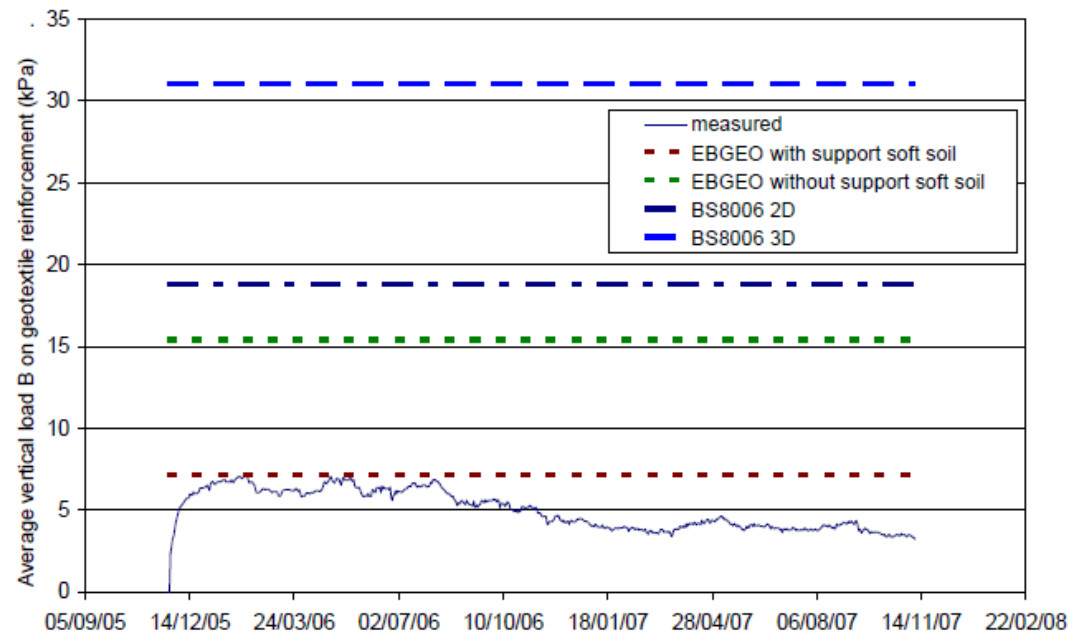

Figure 15 Vertical load carried by the geosynthetic reinforcement [17] 


\section{CRITICAL REVIEW OF THE DESIGN METHODS}

The German and British standards do not differ geosynthetics by type, which is unrealistic because it ignores the interaction between the soil and the geogrid; in other words, it ignores the interlocking effects caused by the inclination of the soil particles in the geogrid apertures. Because the geogrid interacts with the soil particles, depending on the composition and axial stiffness in the plane $(J)$, the interaction should increase the soil stiffness and thus the arching effects. To illustrate this effect, based on research related to improving geogrid reinforced soil [18], we simulated a structure with an increased friction angle of the soil above the geogrid and gained effects of that improvement on the forces on piles and the required tensile strength of the geosynthetics (geogrids). The assumed soil improvement from the interaction with the geogrid was modeled as a $5^{\circ}$ increase in the soil friction angle, which in reality might be even higher. This analysis was conducted using the German standard EBGEO.

Table 5 and Figure 16 show the extent to which these effects changed the load redistribution. For the assumed soil improvement achieved by accounting for the interaction between the soil and geogrid, and by increasing the internal friction angle by $5^{\circ}$ the force on the piles increased by $4.5 \%$; this almost halved the load on the geosynthetics and the ground and reduced the tensile strength of the reinforcement by $63 \%$.

By taking into consideration the interlocking mechanism a more economical solution is provided because it requires a geogrid with lower tensile capacity.

Table 5 Load redistributions with and without the assumption of soil improvement for the geogrid, according to EBGEO

\begin{tabular}{|c|c|c|}
\hline & EBGEO $\varphi_{k}^{\prime}=42^{\circ}$ & EBGEO $\varphi_{k}^{\prime}=47^{\circ}$ \\
\hline Total load (kN) & 508.50 & 508.50 \\
\hline Load directly transferred to piles (kN) & 464.15 & 485.93 \\
\hline Load carried by geosynthetics (kN) & 22.18 & 11.29 \\
\hline Load carried by soft subsoil (kN) & 22.17 & 11.28 \\
\hline Vertical line load $w_{\mathrm{T}}(\mathrm{kN} / \mathrm{m})$ & 19.07 & 7.04 \\
\hline Tensile force $F$ in reinforcement $(\mathrm{kN})$ & 28.61 & 10.56 \\
\hline
\end{tabular}

Load directly on piles (kN)

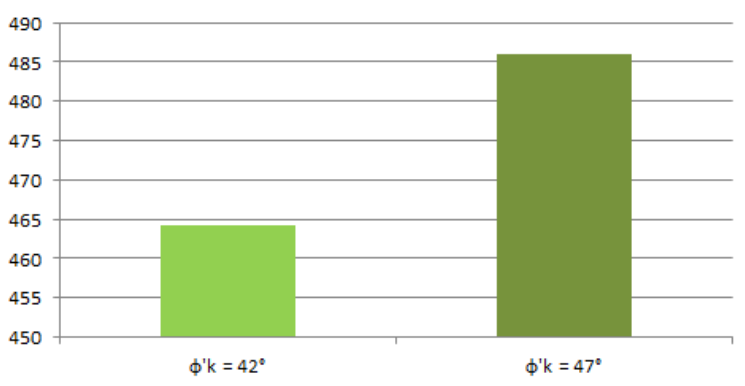

Load carried by geosynthetic $(\mathrm{kN})$

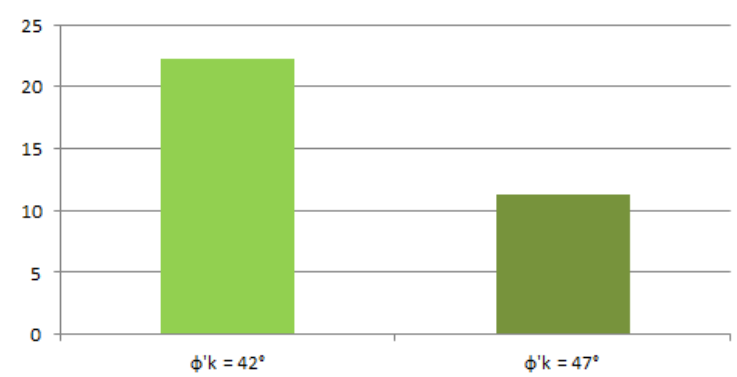

Figure 16 Load redistributions with and without the assumption of soil improvement for the geogrid, according to EBGEO

The differences in the calculation methods are related to the calculation assumptions for the end-bearing and friction piles, the impact values which act on the geosynthetic reinforcement, and the selection criteria for the geosynthetics. The German standard assumes end-bearing piles (i.e., piles embedded on stable soil) and requires certain adjustment when calculating friction piles. In contrast, the British standard can be used to calculate both types of piles using the arching coefficient.

Neither standard analyzes the vertical deformation (settlement) of the subsoil between the piles, necessitating separate calculations, preferably using the finite element method in specialized computer software. Furthermore, neither standard provides a calculation for three-layer reinforcement that does not require special adjustments, even though such a reinforcement layer distribution is sometimes designed and constructed. 


\section{CONCLUSION}

Building embankment foundations on soft soils is a geotechnical problem that can be successfully solved by using reinforced soil platforms over piles. The reinforced soil platforms over piles greatly reduce settlement, construction time of an embankment and consolidation time. The load transfer platform can be designed by using a variety of methods, and some of which we analyzed in this paper. To illustrate the calculation of bearing capacity of a load transfer platform, we used the German standard (EBGEO) and British standard (BS 8006) on an actual embankment on soft soil, and explored their limitations, differences, and similarities. The British standard does not account for the support of soft subsoil, while the German standard does. The German standard provides a calculation for only end-bearing piles, while the British standard assumes end-bearing piles, friction piles, and other types of piles. Neither standard gives results that match the measured values. A source of error in these calculations is not accounting for the type of geosynthetic (geogrid or geotextile), which neglects the very important interlocking effect of the interaction between the soil and geogrid. Also, because these methods do not analyze vertical deformations (settlements) of the soil, a separate calculation of the settlements is required using another method, preferably the finite element method implemented in computer software.

\section{References}

[1] Kempton, G., Naughton, P., 2002: Piled embankments with basal reinforcement: development of design methods and state of the art. Proceedings of the 15th Italian Conference on Geosynthetics.

[2] Holtz, R.D., Massarsch, K. R., 1976: Improvement of the stability of on embankment by piling and reinforced earth. Proceedings of 6th European conference on soil mechanics and foundation engineering, Vol. 1.2., pp. 473-478

[3] Smoltczyk, U., 1976: Pile foundation of a railway embankment. Proceedings of 6 th European conference on soil mechanics and foundation engineering. Vol.1.2, pp. 493-508

[4] Tan, S. B., Tan, S. L., Yang, K. S., Chin, Y. K., 1985: Soil improvement method in Singapore. Proceedings of 3rd International Geotechnical Seminar on Soil Improvement Methods. NTI, Singapore, pp. 249-272

[5] Wood, H.J., 2003: The design and construction of pile-suported embankments for the A63 selby bypass. BGA International Conference on Foundations, Innovations, Observations, Design and Practice. Thomas Telford Services Ltd, London, UK, pp. 941-950

[6] Pottsi, V. J., Zdravkovic, L., 2008: Assessment of BS 8006:1995 Design method for reinforced fill layers above voids. Proceeding of Fourth European Geosynthetics Conference, EuroGeo 4, Paper No. 116

[7] Brandl, H., 2004: Geotechnical aspects for high-speed railways, Proceedings of the International Seminar on Geotechncis in Pavement and Railway Design and Construction, Editor Gomes Correa \& Loizos, Millpress Rotterdam, pp. 117-135.

[8] German Geotechnical Society, 2011: Recommendations for Design and Analysis of Earth Structures using Geosynthetic Reinforcements - EBGEO. Munchen, Ernst \& Sohn

[9] Li, Y., Aubeny, C., Briaud, J., 2002: Geosynthetic Reinforced Pile Supported Embankments. Draft submitted to FHWA. Texas A\&M University, College Station

[10] Guido, V. A., Sweeny, M. A., 1987: Plate loading tests on geogrid-reinforced earth slabs. Proceedings of Geosynthetics Conference, pp. 216-225

[11] Alexiev, D., 2004: Piled embankments for railroads: short overview of methods and significant case studies. Proceedings of the International Seminar on Geotechnics in Pavement and Railway Design and Construction, Roterdam

[12] Hewlett, W. J., Randolph, M. F., 1988: Analysis of piled embankments. Ground Engineering. Vol. 21, No. 3, pp. 12-18

[13] British Standard, BS8006, 1995: Code of practice for Strengthened/reinforced soils and other fills

[14] Van Eekelen, S. J. M, Bezuijen, A., 2008: Design of piled embankments, considering the basic starting points of British Standard BS8006. Proceeding of EuroGeo4 - The Conference, Paper 315

[15] Syawal, S., 2009: Numerical Analysis and Criteria of Embankments on Floating Piles.

[16] Project documentation of the flyover above railroad, 2012

[17] Van Eekelen, S. J. M, Bezuijen, A., Alexiew, D., 2008: Piled embankments in the Netherlands, a fill-scale test, comparing 2 years of measurments with design calculations. Proceeding of Fourth European Geosynthetics Conference, EuroGeo 4, Paper No. 264

[18] Minažek, K., Mulabdić, M., 2013: A review of soil and reinforcement interaction testing in reinforced soil by pullout test. Građevinar 65, No. 3, pp. 235-250 